\title{
The striking geographical pattern of gastric cancer mortality in
} Spain: environmental hypotheses revisited Nuria Aragonés*1,2, Beatriz Pérez-Gómez ${ }^{1,2}$, Marina Pollán ${ }^{1,2}$, Rebeca Ramis ${ }^{1,2}$, Enrique Vidal2,1, Virginia Lope ${ }^{1,2}$, Javier García-Pérez ${ }^{1,2}$, Elena Boldo ${ }^{1,2}$ and Gonzalo López-Abente ${ }^{1,2}$

\author{
Address: ${ }^{2}$ Environmental and Cancer Epidemiology Unit, National Center for Epidemiology, Carlos III Institute of Health, Madrid, Spain and \\ ${ }^{2}$ Consortium for Biomedical Research in Epidemiology \& Public Health (CIBER en Epidemiología y Salud Pública - CIBERESP), Parc de Recerca \\ Biomèdica de Barcelona, Doctor Aiguader, $881^{\text {a }}$ Planta, 8003 Barcelona, Spain \\ Email: Nuria Aragonés* - naragones@isciii.es; Beatriz Pérez-Gómez - bperez@isciii.es; Marina Pollán - mpollan@isciii.es; \\ Rebeca Ramis - rramis@isciii.es; Enrique Vidal - evidal@isciii.es; Virginia Lope - vicarvajal@isciii.es; Javier García-Pérez - jgarcia@isciii.es; \\ Elena Boldo - eiboldo@isciii.es; Gonzalo López-Abente - glabente@isciii.es \\ * Corresponding author
}

Published: 8 September 2009

BMC Cancer 2009, 9:316 doi:10.1186/147|-2407-9-316

This article is available from: http://www.biomedcentral.com/I47I-2407/9/3/6

(c) 2009 Aragonés et al; licensee BioMed Central Ltd.

This is an Open Access article distributed under the terms of the Creative Commons Attribution License (http://creativecommons.org/licenses/by/2.0), which permits unrestricted use, distribution, and reproduction in any medium, provided the original work is properly cited.

\begin{abstract}
Background: Gastric cancer is decreasing in most countries. While socioeconomic development is the main factor to which this decline has been attributed, enormous differences among countries and within regions are still observed, with the main contributing factors remaining elusive. This study describes the geographic distribution of gastric cancer mortality at a municipal level in Spain, from 1994-2003.
\end{abstract}

Methods: Smoothed relative risks of stomach cancer mortality were obtained, using the BesagYork-Molliè autoregressive spatial model. Maps depicting relative risk (RR) estimates and posterior probabilities of RR being greater than I were plotted.

Results: From 1994-2003, 62184 gastric cancer deaths were registered in Spain (7 percent of all deaths due to malignant tumors). The geographic pattern was similar for both sexes. RRs displayed a south-north and coast-inland gradient, with lower risks being observed in Andalusia, the Mediterranean coastline, the Balearic and Canary Islands and the Cantabrian seaboard. The highest risk was concentrated along the west coast of Galicia, broad areas of the Castile \& Leon Autonomous community, the province of Cáceres in Extremadura, Lleida and other areas of Catalonia.

Conclusion: In Spain, risk of gastric cancer mortality displays a striking geographic distribution. With some differences, this persistent and unique pattern is similar across the sexes, suggesting the implication of environmental exposures from sources, such as diet or ground water, which could affect both sexes and delimited geographic areas. Also, the higher sex-ratios found in some areas with high risk of smoking-related cancer mortality in males support the role of tobacco in gastric cancer etiology. 


\section{Background}

Gastric cancer has plotted a trend very different to that of other malignant tumors in recent decades, with a marked decline in incidence and mortality, described by the scientific community as an "unplanned triumph" [1]. However, this tumor still ranks fourth in terms of incidence and second in cancer mortality worldwide [2]; in 2002, there were more than 900,000 new cases of gastric cancer around the world, 66\% of which occurred in less developed countries [3].

One of this tumor's epidemiologic characteristics is the presence of marked geographic differences worldwide. The highest incidence rates have been reported in Korean and Japanese cancer registries, where rates are tenfold those of the United States. Interestingly, the world geographic risk pattern is very similar in both sexes, with the sex ratio being stable -generally in the order of 2- across high and low incidence regions [3]. This fact suggests that environmental exposures might play an important role in this tumor's carcinogenesis, which is not yet well understood.

Overall, gastric tumors account for more than $90 \%$ of adenocarcinomas (AC) but there are two well-differentiated AC groups, namely, intestinal and diffuse type [4], with different clinical, epidemiologic and pathologic characteristics. The intestinal type is more prevalent among men and the elderly, tends to be sited in the noncardia portions of the stomach, and is predominant in the lowest socioeconomic groups and high risk areas. Furthermore, it is the type to which the decline in gastric cancer in high-risk populations has been attributed $[5,6]$. Diet and H. pylori infection are considered the most important factors involved in this type of cancer. Diffuse AC, with an M:F ratio bordering on unity, is the most usual histological type in gastric cardia neoplasms, is more frequent among the young, and has been linked to constitutionally-related factors $[7,8]$.

As mentioned above, gastric cancer has been related with socioeconomic status. At an individual level, this variable can be linked to dietary patterns, infection by Helicobacter pylori, tobacco use, and, to a lesser extent, occupational exposures taking place in less qualified jobs $[9,10]$. At an ecologic level, this variable might reflect differences in environmental exposures associated with pollution and other hazardous exposures $[11,12]$. Yet, the relationship between this variable and gastric cancer frequency is not universally robust, since countries with a high socioeconomic level, such as Japan, maintain high rates of this disease.

In Spain, previous geographic studies using provinces as study units have shown that gastric cancer mortality rates displayed a singular spatial distribution, which was simi- lar across the sexes and different from that of any other tumor [13]. Moreover, this pattern -with some changeshas been very consistent over recent decades. In order to improve the description of the high-risk areas, in this paper we use data aggregated at municipal level, the smallest geographic administrative boundaries that can be used for the whole country. This approach presents some limitations, since sparsely populated areas with few or zero cases can generate extreme RR values. However, recent advances in the field of spatial epidemiology have opened the way to new methods of disease mapping which enable these challenges to be successfully met [14]. The most widely used strategy for tackling the problems posed by small-area analysis is to estimate the spatial distribution of risk by means of simulation based on Bayesian hierarchical models. Analysis of small areas improves the interpretation of results and the capacity to detect local effects linked to environmental problems, while reducing ecologic biases.

The objective of this study was to show the spatial distribution patterns of gastric cancer mortality in men and women in Spain, and help to generate new hypotheses which might serve to explain these patterns. On the assumption that lung cancer mortality is linked to the prevalence of tobacco smokers, we also show maps depicting the municipal distribution of lung cancer mortality in Spain.

\section{Methods}

As case source, we used individual death entries for the period 1994-2003 corresponding to gastric cancer (International Classification of Diseases, $9^{\text {th }}$ revision [ICD-9], code 151) and lung cancer (ICD-9 code 162). These data, which include information on town of residence at death, were supplied by the National Statistics Institute broken down by age group (18 groups) and sex. The municipal populations, also broken down by age group and sex, were drawn from the 1996 electoral roll and 2001 census. These years correspond to the midway points of the two quinquennia that comprise the study period (1994-1998 and 1999-2003). The person-years for each five-year period were estimated by multiplying these populations by 5 .

The methodology has been explained elsewhere in more detail [15]. Briefly, gastric cancer standardized mortality ratios (SMRs) were computed as the ratio between the observed and the expected number of deaths. For the calculation of expected cases, the overall age-specific Spanish mortality rates for the two 5-year periods were multiplied by each town's person-years, broken down by age group, sex, and quinquennium.

Smoothed municipal relative risks (RRs) for map-plotting purposes were estimated, by fitting spatial Poisson mod- 
els with two random-effects terms that took the following into account: a) municipal contiguity (spatial term); and b) municipal heterogeneity. These models come within the category of the so-called conditional autoregressive (CAR) models proposed by Besag, York and Mollié [16], and were fitted using Bayesian Markov chain Monte Carlo simulation methods with non-informative priors [17]. Convergence of the simulations was verified using the BOA (Bayesian Output Analysis) R program library [18]. Given the great number of parameters of the models, the convergence analysis was performed on a randomly selected sample of 10 towns and cities, taking strata defined by municipal size. Posterior distributions of relative risk were obtained using WinBugs [19]. The criterion of contiguity used was adjacency of municipal boundaries. Results from these models were included in a Geographic Information System to plot maps that depicted smoothed RR estimates and the distribution of the posterior probability that $R R>1$ (Bayesian version of $p$ value). Insofar as this indicator is concerned, probabilities above 0.8 should be deemed statistically significant $[20]$. Thereafter, we calculated the ratio of estimated RRs in males and females by municipality.

Additionally, a similar model was constructed for lung cancer (only men); its spatial pattern might be considered a surrogate indicator of the smokers male prevalence in Spain.

\section{Results}

From 1994 to 2003, a total of 62184 gastric cancer deaths were registered in Spain (37963 in men, and 24221 in women), accounting for $7 \%$ of all deaths due to malignant tumors nationwide in this period. Table 1 lists a number of descriptive statistics for both sexes.

To give an overall picture, Figure 1 shows age-standardized rates of gastric cancer mortality by province. Also by way of reference, Table 2 presents the provincial age- standardized rates (ASR) of gastric cancer mortality by sex. The province with highest mortality in both sexes was Burgos (ASR in men: 31.01; ASR in women: 13.81), followed by Palencia y Pontevedra. In contrast, Santa Cruz de Tenerife and the Balearic Islands presented the lowest mortality rates in men and women respectively (ASR in men 10.88 and ASR in women 4.46).

Figures 2 and 3 depict the smoothed RRs for males and females, together with the spatial distribution of posterior probabilities of having a relative risk greater than 1 in each sex. The smoothed RR maps enable homogeneous areas to be delimited. In men, there was a huge area of excess risk that covered: the Autonomous Community of Castile \& Leon; the western half of Cáceres and the north of Badajoz in Extremadura; specific areas in the provinces of Toledo, Guadalajara, Cuenca and Ciudad Real in Castile-La Mancha; La Rioja; and, Navarre and the Basque Country. In addition, there were two areas with clear excess risk, i.e., the Atlantic coast of Galicia and the interior of Catalonia, comprising the districts of Ripollés in the province of Girona, and Pallars Sobirá and Alto Urgel in Lleida.

While the general pattern was very similar among women, some differences were nevertheless in evidence. The excess risk area corresponding to Castile \& Leon was larger, in that it included almost the entire province of Cáceres, all four provinces of Galicia, and most of the territory in Aragon. In contrast, no increased risk was observed in the northern areas of the Basque Country and Navarre. A noteworthy feature was the marked south-north and coast-inland pattern of gastric cancer mortality in both sexes, with a relatively significant, low risk of dying from this cancer in the Spain's Andalusian and Mediterranean provinces, the Canary and Balearic Islands, and part of the Cantabrian coastline.

Shown in Table 3 are the SMRs and RRs for a selection of towns with excess risk of gastric cancer mortality. Towns

Table I: Summary of population and gastric cancer mortality in Spain's 8072 towns and cities, 1994-2003.

\begin{tabular}{|c|c|c|c|c|c|c|c|c|c|}
\hline & Total & Mean & $\begin{array}{l}\text { Standard } \\
\text { Deviation }\end{array}$ & Min. & Max. & PIO & Median & P90 & No. (\%) with zero counts \\
\hline \multicolumn{10}{|l|}{ MEN } \\
\hline Population & 19698855 & 2440 & 20161 & 3 & 1356000 & 48 & 293 & 3626 & 0 \\
\hline Observed & 37963 & 4.70 & 39.36 & 0 & 2746 & 0 & $\mathrm{I}$ & 7 & 3205 \\
\hline Expected & 38199 & 4.73 & 41.66 & 0.01 & 2874 & 0.19 & 0.94 & 7.24 & 0 \\
\hline SMR & - & 1.04 & 1.61 & 0 & 28.57 & 0 & 0.69 & 2.59 & 3205 \\
\hline RR & - & 1.08 & 0.22 & 0.41 & 2.55 & 0.83 & 1.04 & 1.38 & 0 \\
\hline \multicolumn{10}{|l|}{ WOMEN } \\
\hline Population & 20549210 & 2545 & 22612 & I & 1547000 & 43 & 281 & 3690 & 0 \\
\hline Observed & 24221 & 3.00 & 28.01 & 0 & 1959 & 0 & 0 & 5 & 4156 \\
\hline Expected & 24315 & 3.01 & 29.97 & 0.00 & 2089 & 0.10 & 0.54 & 4.50 & 0 \\
\hline SMR & - & 1.07 & 2.28 & 0 & 50.00 & 0 & 0 & 2.75 & 4156 \\
\hline$R R$ & - & 1.10 & 0.25 & 0.23 & 2.63 & 0.84 & 1.06 & 1.41 & 0 \\
\hline
\end{tabular}




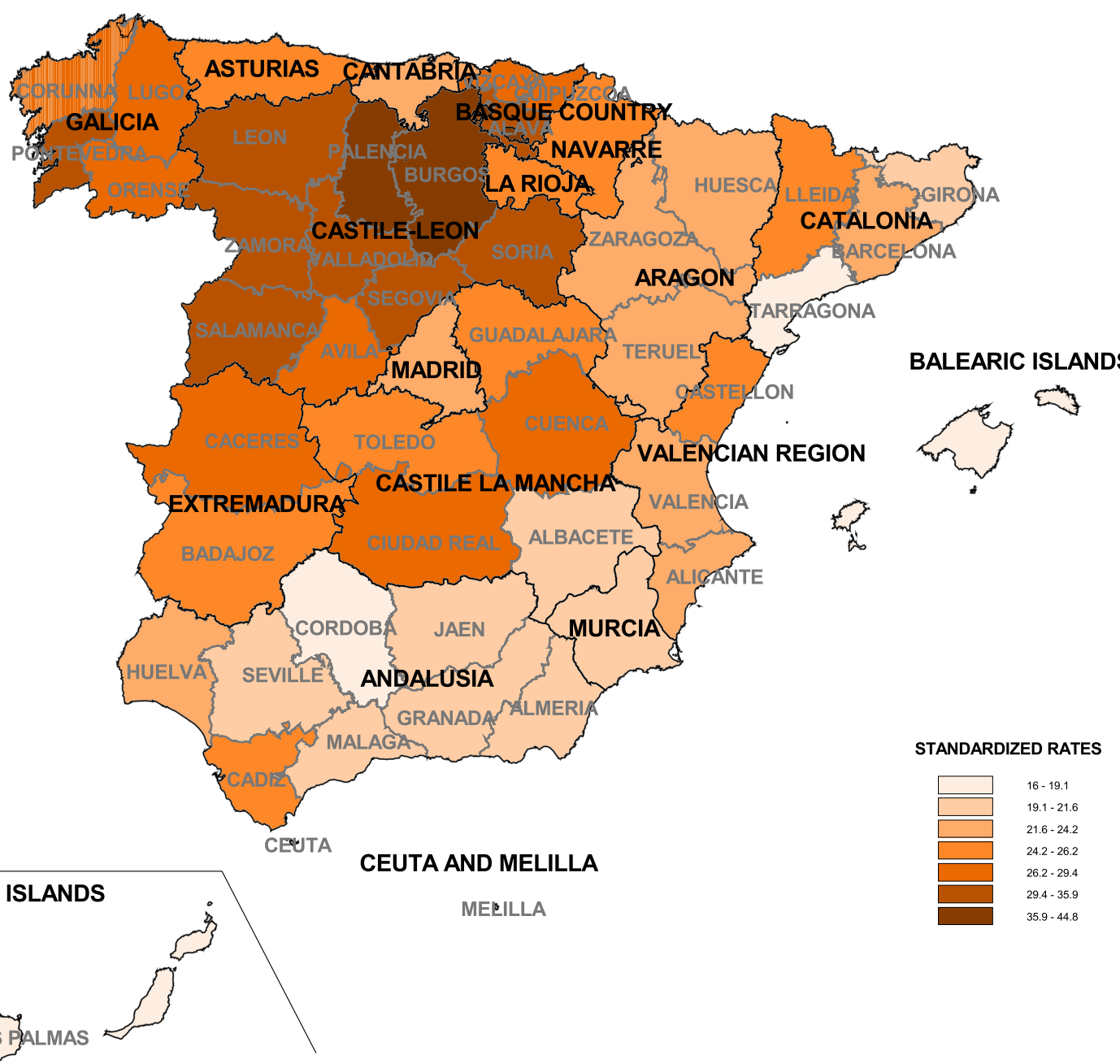

Figure I

Provincial age-standardized gastric cancer mortality rates (both sexes). Spain, 1994-2003.

were required to have RRs of over 1.50, based on a difference between observed and expected numbers equal to or greater than 3 cases, and a posterior probability of over 0.9: a total of 67 towns, belonging to 7 Autonomous Communities, met these criteria. A total of $55 \%$ of the towns selected were situated in Galicia, specifically in the provinces of Pontevedra and Corunna. Attention should be drawn to the fact that 9 of the 10 towns with highest excess risk in men and women were Galician, and that 7 of these, all lying in the province of Pontevedra, were the same for both sexes (Bueu, Cangas, A Guarda, Vilaboa, Moaña, O Grove and Marín). Indeed, Bueu and Cangas were the towns that registered the highest RRs in the whole of Spain, for men and women alike.

Figure 4 depicts the sex ratios obtained on the basis of smoothed RRs, along with the distribution lung cancer mortality in men. It is noteworthy that the areas of highest risk of dying from lung cancer in men present the highest gastric cancer mortality sex ratios.

\section{Discussion}

This study highlights the persistence of a marked geographic pattern in risk of gastric cancer mortality in Spain, which affects both sexes and which has not been observed for any other tumor. Special mention should be made of the high risk that extends across a broad swathe of the Northern Iberian Plateau (Meseta), covering the Autonomous Region of Castile \& Leon and spreading northeast towards the Basque Country, Navarre and La Rioja, and west to Portugal and northern Extremadura. In addition, two further areas with excess risk were identified, namely, the Atlantic Coast of Galicia and the interior of Catalonia. This pattern's similarity in men and women and its maintenance over time suggest that distribution of stomach cancer here in Spain could be related to long-standing environmental exposures shared by both sexes, as gastric cancer is known to be the result of decades of interaction between chronic inflammation and exposure to carcinogens. 
Table 2: Age-standardized gastric cancer mortality rates by sex and province in Spain, 1994-2003.

\begin{tabular}{|c|c|c|c|c|c|c|}
\hline \multirow[b]{2}{*}{$\begin{array}{l}\text { Autonomous } \\
\text { Region }\end{array}$} & \multirow[b]{2}{*}{ Province } & \multicolumn{2}{|c|}{ Men } & \multicolumn{2}{|c|}{ Women } & \multirow[b]{2}{*}{$\begin{array}{c}\text { Male:female } \\
\text { Ratio }\end{array}$} \\
\hline & & $\begin{array}{r}\text { Observed } \\
\text { cases }\end{array}$ & ASR & $\begin{array}{r}\text { Observed } \\
\text { cases }\end{array}$ & ASR & \\
\hline \multirow[t]{8}{*}{ Andalusia } & Almería & 331 & 14.14 & 193 & 6.41 & 2.21 \\
\hline & Cádiz & 828 & 18.35 & 485 & 7.51 & 2.44 \\
\hline & Córdoba & 554 & 13.67 & 316 & 5.44 & 2.51 \\
\hline & Granada & 620 & 14.35 & 399 & 6.87 & 2.09 \\
\hline & Huelva & 364 & 15.75 & 243 & 7.56 & 2.08 \\
\hline & Jaén & 527 & 14.59 & 302 & 6.80 & 2.15 \\
\hline & Málaga & 843 & 14.33 & 425 & 5.20 & 2.76 \\
\hline & Sevilla & 1126 & 14.93 & 650 & 5.83 & 2.56 \\
\hline \multirow[t]{3}{*}{ Aragon } & Huesca & 284 & 15.77 & 192 & 8.43 & 1.87 \\
\hline & Teruel & 178 & 15.00 & 126 & 8.14 & 1.84 \\
\hline & Zaragoza & 875 & 15.60 & 631 & 7.47 & 2.09 \\
\hline Asturias & Asturias & 1242 & 17.45 & 875 & 7.83 & 2.23 \\
\hline Balearic Islands & Balearic Islands & 485 & 11.61 & 266 & 4.46 & 2.60 \\
\hline \multirow[t]{3}{*}{ Basque Country } & Alava & 351 & 22.87 & 198 & 9.37 & 2.44 \\
\hline & Guipuzcoa & 748 & 19.74 & 410 & 7.25 & 2.72 \\
\hline & Vizcaya & 1312 & 20.33 & 726 & 7.55 & 2.69 \\
\hline \multirow[t]{2}{*}{ Canary Islands } & Las Palmas & 440 & 12.70 & 250 & 5.40 & 2.35 \\
\hline & St.Cruz Tenerife & 397 & 10.88 & 254 & 5.11 & 2.13 \\
\hline Cantabria & Cantabria & 544 & 16.59 & 333 & 6.49 & 2.56 \\
\hline \multirow{5}{*}{ Castile la Mancha } & Albacete & 308 & 14.64 & 189 & 6.95 & 2.11 \\
\hline & Ciudad Real & 560 & 19.35 & 349 & 8.20 & 2.36 \\
\hline & Cuenca & 310 & 19.22 & 161 & 7.77 & 2.47 \\
\hline & Guadalajara & 214 & 17.81 & 128 & 8.42 & 2.12 \\
\hline & Toledo & 601 & 17.95 & 382 & 8.18 & 2.20 \\
\hline \multirow[t]{9}{*}{ Castile-Leon } & Avila & 315 & 21.30 & 160 & 8.09 & 2.63 \\
\hline & Burgos & 740 & 31.01 & 479 & $|3.8|$ & 2.25 \\
\hline & Leon & 813 & 21.90 & 513 & 9.35 & 2.34 \\
\hline & Palencia & 355 & 28.38 & 244 & 12.64 & 2.25 \\
\hline & Salamanca & 561 & 21.31 & 357 & 9.86 & 2.16 \\
\hline & Segovia & 275 & 24.05 & 169 & 10.71 & 2.25 \\
\hline & Soria & 191 & 22.24 & 126 & 10.70 & 2.08 \\
\hline & Valladolid & 657 & 22.74 & 415 & 9.69 & 2.35 \\
\hline & Zamora & 385 & 21.90 & 244 & 10.08 & 2.17 \\
\hline \multirow[t]{4}{*}{ Catalonia } & Barcelona & 4063 & $|5.4|$ & 2679 & 6.65 & 2.32 \\
\hline & Girona & 465 & 13.89 & 330 & 6.87 & 2.02 \\
\hline & Lleida & 474 & 17.35 & 276 & 7.44 & 2.33 \\
\hline & Tarragona & 475 & 13.13 & 277 & 5.66 & 2.32 \\
\hline \multirow[t]{2}{*}{ Extremadura } & Badajoz & 666 & 17.90 & 360 & 6.75 & 2.65 \\
\hline & Cáceres & 536 & 19.98 & 349 & 8.82 & 2.27 \\
\hline \multirow[t]{4}{*}{ Galicia } & A Coruña & 1317 & 19.84 & 907 & 8.71 & 2.28 \\
\hline & Lugo & 567 & 17.73 & 403 & 9.14 & 1.94 \\
\hline & Ourense & 518 & 17.50 & 416 & 9.24 & 1.89 \\
\hline & Pontevedra & 1144 & 24.21 & 906 & 11.69 & 2.07 \\
\hline La Rioja & La Rioja & 323 & 18.10 & 180 & 7.51 & 2.41 \\
\hline Madrid & Madrid & 4084 & 15.92 & 2799 & 7.00 & 2.27 \\
\hline Murcia & Murcia & 781 & 14.29 & 540 & 7.29 & 1.96 \\
\hline Navarre & Navarre & 599 & 17.93 & 376 & 7.83 & 2.29 \\
\hline \multirow[t]{3}{*}{ Valencian Region } & Alacant & 1165 & 15.55 & 687 & 7.02 & 2.22 \\
\hline & Castello & 483 & 16.76 & 307 & 8.11 & 2.07 \\
\hline & Valencia & 1895 & 16.23 & 1187 & 7.05 & 2.30 \\
\hline Ceuta & Ceuta & 46 & 16.18 & 28 & 6.85 & 2.36 \\
\hline Melilla & Melilla & 28 & 10.01 & 25 & 7.71 & 1.30 \\
\hline
\end{tabular}

ASR = Age-Standardized Rate. 
a)

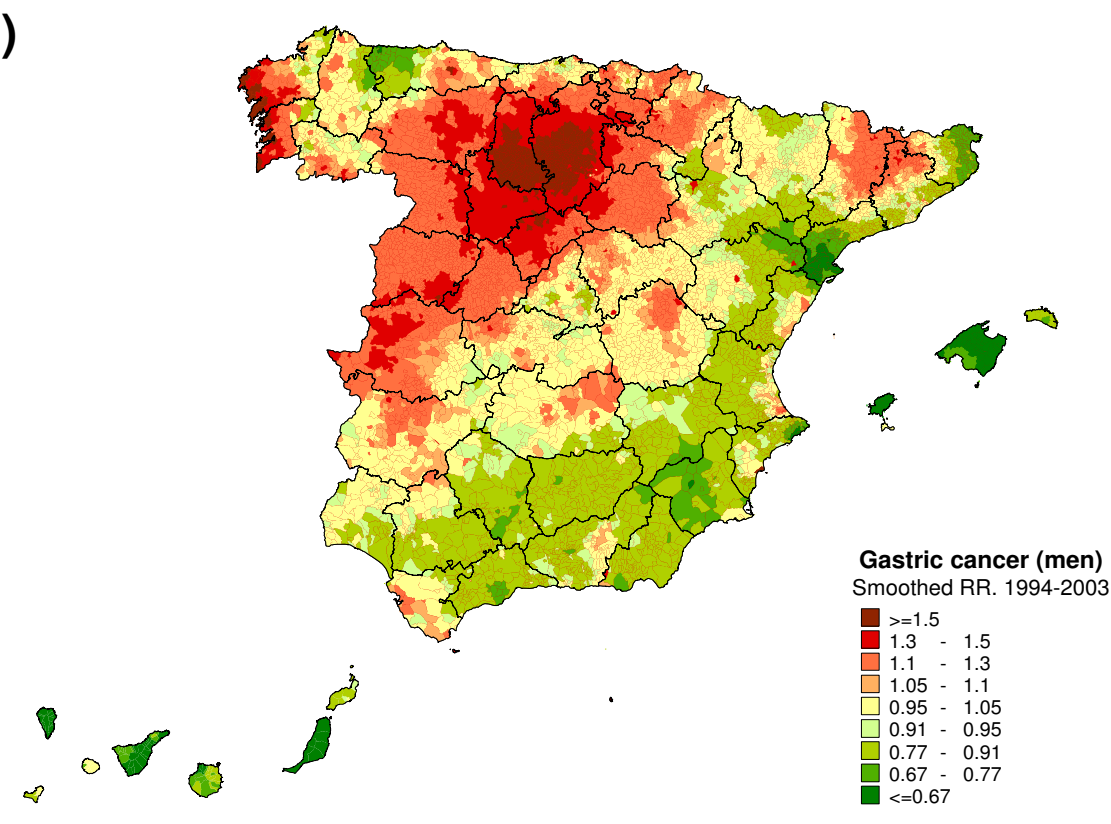

b)

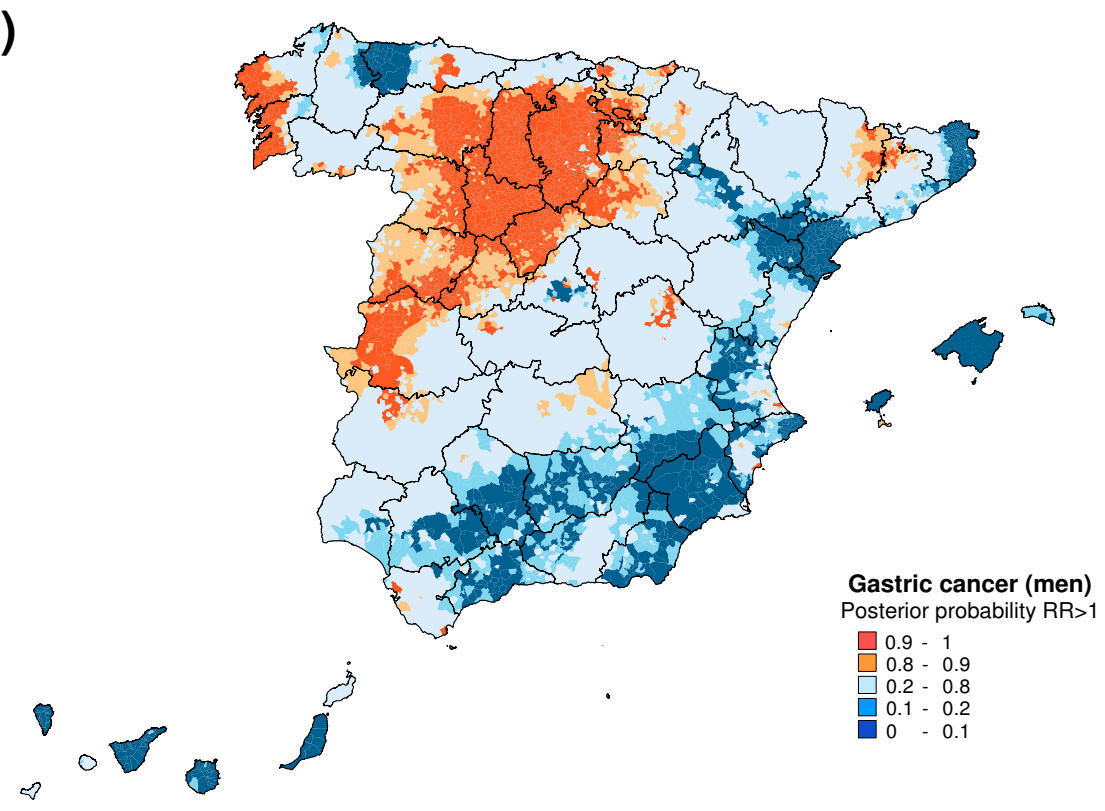

Figure 2

Municipal distribution of gastric cancer mortality in men: a) smoothed relative risk (RR); b) posterior probability of RR being greater than I. Spain, 1994-2003.

When it comes to interpreting the results, some factors must be taken into account. Firstly, mortality is not the best indicator for studying cancer distribution. However, mortality continues to be the only comprehensive source of cancer information in Spain. Though the geographic distribution of specific-cause mortality might be affected by differences in the quality of death certification between one part of the country and another, there are not too many arguments that could support possible inconsistencies and differences of criteria in the coding of death certificates. Gastric cancer is a well-certified cause of death in Spain, with detection and confirmation rates both exceeding $80 \%$ [21]. Another explanation for possible differences in cancer mortality among regions refers to variation in survival rates due to differences in the health care system across the country. Bearing in mind the char- 
a)

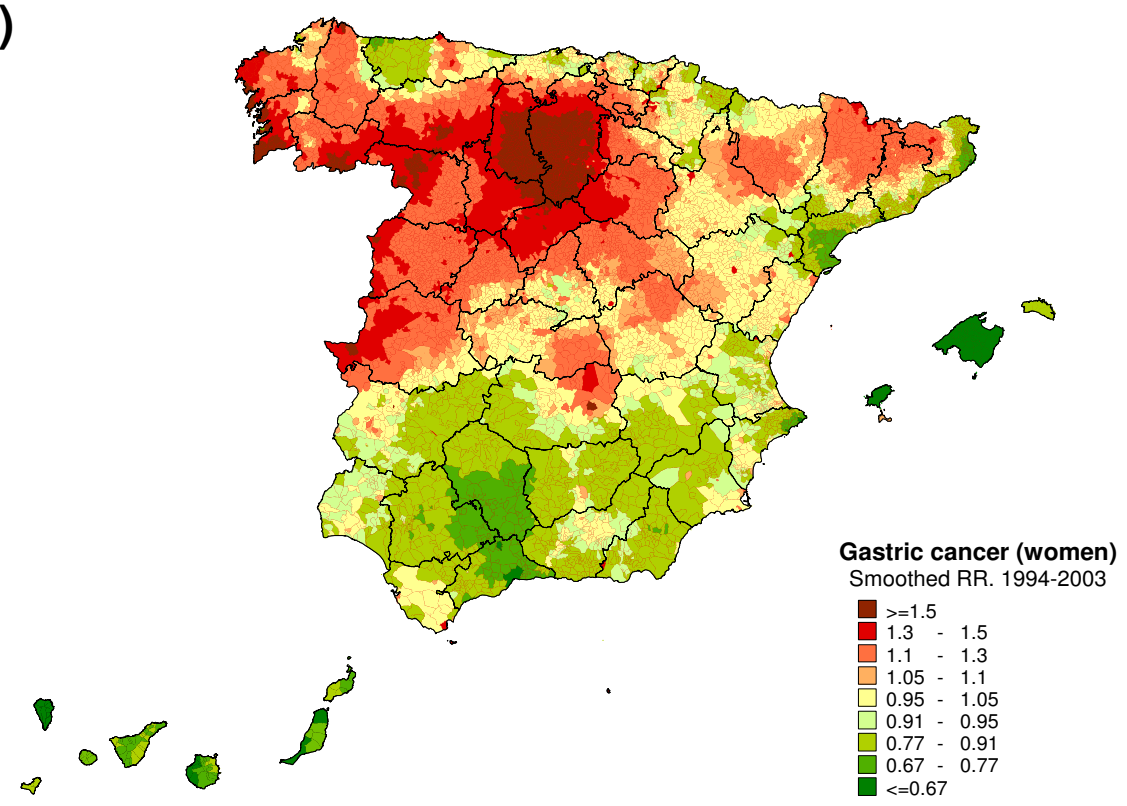

b)

Figure 3

Municipal distribution of gastric cancer mortality in women: a) smoothed relative risk (RR); b) posterior probability of RR being greater than I. Spain, 1994-2003.

acteristics of the Spanish National Health Care System, with universal accessibility, we would have no reason to suspect that there might be differential access to health care and diagnosis between regions.

The methodology used for the study of spatial disease patterns has traditionally relied on standardized mortality ratios (SMRs) [14]. For small geographic units, the use of SMRs introduces an extra source of variability, in the form of random variability, since sparsely populated areas with few or zero cases can generate extreme SMR values [14]. The Bayesian approach attempts to solve this problem, by using smoothing techniques that help identify the underlying geographic pattern. This approach is not entirely free of limitations, however, and there are authors who feel that Bayesian disease-mapping models are essentially conservative [20]. 
Table 3: Towns with 5 or more gastric cancer deaths which have shown RRs of over 1.5 in men or women, based on a difference between the number of observed and expected deaths equal to or greater than 3 , and a posterior probability $>=0.9$ (1994-2003).

\begin{tabular}{|c|c|c|c|c|c|c|c|c|c|c|}
\hline \multirow[t]{2}{*}{ Autonomous region } & \multirow[t]{2}{*}{ Province } & \multirow[t]{2}{*}{ Town } & \multicolumn{4}{|c|}{ Males } & \multicolumn{4}{|c|}{ Females } \\
\hline & & & Observed & Expected & SMR & $\mathbf{R R}$ & Observed & Expected & SMR & $\mathbf{R} \mathbf{R}$ \\
\hline Asturias & Asturias & Langreo & 93 & 52.1 & 1.79 & 1.57 & 45 & 36.7 & 1.23 & 1.21 \\
\hline Castile La Mancha & Ciudad Real & Solana (la) & 21 & 14.1 & 1.49 & 1.18 & 22 & 8.4 & 2.63 & $\mid .51$ \\
\hline \multirow[t]{24}{*}{ Castile \& Leon } & Burgos & Aranda de Duero & 38 & 26.4 & $\mathrm{I} .44$ & 1.45 & 31 & 15.6 & 1.99 & 1.68 \\
\hline & & Belorado & 7 & 3.3 & 2.12 & 1.48 & 7 & 2.0 & 3.44 & 1.55 \\
\hline & & Briviesca & 13 & 6.2 & 2.10 & 1.52 & 8 & 4.0 & 2.02 & 1.58 \\
\hline & & Burgos & 341 & 151.4 & 2.25 & 2.13 & 208 & 102.3 & 2.03 & 1.97 \\
\hline & & Ibeas de Juarros & 5 & 1.5 & 3.29 & 1.74 & 1 & 0.7 & 1.40 & 1.75 \\
\hline & & Lerma & 5 & 2.9 & 1.74 & 1.63 & 5 & 1.8 & 2.71 & 1.94 \\
\hline & & Salas de los Infantes & 7 & 2.9 & 2.38 & 1.63 & I & 1.6 & 0.63 & 1.49 \\
\hline & & Sasamón & 8 & 2.7 & 2.94 & 1.62 & 2 & 1.5 & 1.34 & 1.73 \\
\hline & Leon & Bustillo del Páramo & 4 & 3.1 & 1.29 & 1.30 & 7 & 1.7 & 4.20 & 1.59 \\
\hline & & Santa María del Páramo & 3 & 3.2 & 0.93 & 1.33 & 8 & 1.9 & 4.12 & 1.76 \\
\hline & & Villarejo de Órbigo & 1 & 5.2 & 0.19 & 1.15 & 9 & 3.1 & 2.88 & 1.52 \\
\hline & Palencia & Becerril de Campos & 6 & 1.8 & 3.35 & 1.63 & 4 & 1.3 & 3.19 & 1.63 \\
\hline & & Carrión de los Condes & 6 & 3.0 & 2.00 & 1.58 & 4 & 2.6 & 1.56 & 1.54 \\
\hline & & Dueñas & 7 & 3.4 & 2.04 & 1.59 & 2 & 1.8 & 1.12 & 1.57 \\
\hline & & Palencia & 133 & 76.7 & 1.74 & 1.68 & 89 & 53.2 & 1.67 & 1.65 \\
\hline & & Saldaña & 12 & 3.6 & 3.30 & 1.59 & 7 & 2.3 & 3.06 & 1.55 \\
\hline & & Venta de Baños & 9 & 6.4 & 1.40 & 1.55 & 8 & 4.1 & 1.96 & 1.69 \\
\hline & & Villada & 4 & 1.9 & 2.13 & 1.51 & 7 & 1.6 & 4.41 & 1.52 \\
\hline & & Villarramiel & 5 & 1.4 & 3.62 & 1.58 & I & I.I & 0.89 & 1.42 \\
\hline & Salamanca & Bejar & 39 & 19.8 & 1.97 & 1.57 & 22 & 13.6 & 1.62 & 1.34 \\
\hline & & Hinojosa de Duero & 2 & 1.6 & 1.24 & 1.20 & 6 & 1.1 & 5.59 & 1.53 \\
\hline & Valladolid & Laguna de Duero & 13 & 7.4 & 1.75 & 1.51 & 5 & 3.8 & 1.32 & 1.37 \\
\hline & & Peñafiel & 10 & 5.9 & 1.69 & 1.48 & 10 & 3.8 & 2.60 & 1.67 \\
\hline & Zamora & Gallegos del Río & 2 & 1.8 & 1.14 & 1.19 & 5 & 1.0 & 5.12 & 1.60 \\
\hline Valencian Region & Alicante & Santa Pola & 35 & 15.4 & 2.27 & 1.84 & 8 & 8.6 & 0.93 & 0.99 \\
\hline Cantabria & Cantabria & Reinosa & 22 & 13.4 & 1.64 & 1.51 & 7 & 8.9 & 0.79 & 0.97 \\
\hline \multirow[t]{2}{*}{ Extremadura } & Badajoz & Calamonte & 7 & 4.7 & 1.48 & 1.28 & 12 & 2.7 & 4.39 & 2.00 \\
\hline & Cáceres & Membrio & I & 1.7 & 0.59 & 1.25 & 6 & I.I & 5.38 & 1.53 \\
\hline \multirow[t]{27}{*}{ Galicia } & Corunna & Boiro & 31 & 16.0 & 1.94 & 1.75 & 15 & 11.0 & 1.37 & 1.41 \\
\hline & & Camariñas & 20 & 6.7 & 2.96 & 2.02 & 6 & 4.5 & 1.33 & 1.38 \\
\hline & & Carnota & 16 & 7.2 & 2.24 & 1.82 & 10 & 5.6 & 1.78 & $\mid .51$ \\
\hline & & Cee & 12 & 7.0 & 1.72 & 1.51 & 7 & 5.0 & $\mathrm{I} .4 \mathrm{I}$ & 1.41 \\
\hline & & Lousame & 14 & 5.7 & 2.48 & 1.69 & 5 & 4.0 & 1.24 & $\mid .31$ \\
\hline & & Malpica de Bergantiños & 13 & 8.5 & 1.53 & 1.32 & 13 & 5.8 & 2.24 & 1.63 \\
\hline & & Mazaricos & 15 & 7.1 & 2.12 & 1.57 & 6 & 5.7 & 1.06 & 1.33 \\
\hline & & Muros & 28 & 10.5 & 2.66 & 2.00 & 16 & 8.2 & 1.95 & 1.55 \\
\hline & & Noia & 26 & 12.8 & 2.04 & 1.73 & 15 & 9.9 & 1.51 & 1.38 \\
\hline & & Porto do son & 17 & 10.1 & 1.69 & 1.70 & 14 & 7.7 & 1.81 & 1.55 \\
\hline & & Puebla del Caramiñal & 17 & 9.3 & 1.82 & 1.73 & 12 & 6.8 & 1.77 & 1.61 \\
\hline & & Ribeira & 37 & 23.2 & 1.60 & 1.64 & 28 & 15.4 & 1.81 & $|.7|$ \\
\hline & Lugo & Xove & 2 & 4.5 & 0.45 & 1.02 & 8 & 2.8 & 2.91 & 1.58 \\
\hline & Orense & Cualedro & 5 & 4.9 & 1.02 & 1.09 & 10 & 2.7 & 3.66 & 1.64 \\
\hline & & Monterrei & 5 & 6.9 & 0.72 & 1.10 & 8 & 3.9 & 2.06 & 1.67 \\
\hline & & Verín & 28 & 14.7 & 1.90 & 1.38 & 25 & 9.0 & 2.77 & 1.95 \\
\hline & Pontevedra & Bueu & 33 & 10.4 & 3.18 & 2.55 & 21 & 6.8 & 3.08 & 2.63 \\
\hline & & Cambados & 18 & 10.8 & 1.66 & 1.61 & 9 & 7.1 & 1.26 & 1.63 \\
\hline & & Cangas & 49 & 19.0 & 2.58 & 2.46 & 31 & 12.7 & 2.44 & 2.48 \\
\hline & & Gondomar & 15 & 9.1 & 1.65 & 1.40 & 11 & 5.9 & 1.85 & 1.57 \\
\hline & & Grove (o) & 21 & 9.6 & 2.19 & 1.89 & 18 & 6.3 & 2.84 & 2.33 \\
\hline & & Guarda (a) & 25 & 8.5 & 2.94 & 2.43 & 16 & 6.1 & 2.62 & 2.36 \\
\hline & & Marín & 35 & 19.1 & 1.83 & 1.87 & 27 & 13.2 & 2.05 & 2.10 \\
\hline & & Meis & 9 & 4.9 & 1.83 & 1.52 & 7 & 3.8 & 1.83 & 1.54 \\
\hline & & Moaña & 23 & 14.3 & 1.61 & 1.95 & 27 & 9.7 & 2.77 & 2.50 \\
\hline & & Mos & 16 & 11.2 & 1.43 & 1.40 & 12 & 7.5 & 1.59 & 1.54 \\
\hline & & Neves (as) & 9 & 6.0 & 1.51 & 1.29 & 10 & 4.4 & 2.26 & 1.65 \\
\hline
\end{tabular}


Table 3: Towns with 5 or more gastric cancer deaths which have shown RRs of over 1.5 in men or women, based on a difference between the number of observed and expected deaths equal to or greater than 3 , and a posterior probability $>=0.9$ (1994-2003).

\begin{tabular}{|c|c|c|c|c|c|c|c|c|}
\hline Nigrán & 11 & 11.8 & 0.93 & 1.24 & 13 & 8.3 & 1.57 & 1.54 \\
\hline Ponteareas & 24 & 15.9 & $\mid .51$ & 1.38 & 27 & II.I & 2.44 & 1.74 \\
\hline Redondela & 39 & 22.9 & 1.70 & 1.52 & 22 & 16.0 & 1.38 & 1.45 \\
\hline Rosal (o) & 8 & 6.1 & 1.30 & 1.66 & 11 & 4.4 & 2.52 & 2.00 \\
\hline Salvaterra do Miño & 14 & 8.6 & 1.64 & 1.35 & 15 & 6.5 & 2.31 & 1.66 \\
\hline Sanxenxo & 18 & 14.5 & 1.24 & 1.43 & 14 & 9.3 & $1.5 \mathrm{I}$ & 1.64 \\
\hline Tui & 20 & 13.9 & 1.44 & 1.39 & 16 & 10.7 & 1.49 & 1.54 \\
\hline Vilaboa & 18 & 5.7 & 3.14 & 2.05 & 11 & 3.9 & 2.79 & 2.16 \\
\hline Vilagarcía de Arousa & 49 & 28.2 & 1.74 & 1.58 & 39 & 19.5 & 2.00 & 1.72 \\
\hline Vilanova de Arousa & 26 & 13.8 & 1.89 & 1.73 & 29 & 9.2 & 3.14 & 2.40 \\
\hline
\end{tabular}

SMR = Standard Mortality Ratio. $R R=$ Relative Risk. $\mathrm{PP}=$ posterior probability that $\mathrm{RR}>\mathrm{I}$.

As previously mentioned, in Spain the gastric cancer mortality risk pattern is characterized by its singularity, the enormous similarity it displays across the sexes, and its persistence over time, inasmuch as its pattern has been known since the 1980s [22]. This pattern might partially be explained by geographic differences in the prevalence of Helicobacter pylori infection. This bacterium was classified as a carcinogen (Group 1) by the International Agency for Research on Cancer in 1994, due to its relationship with gastric cancer [23], and is currently viewed as the principal risk factor for noncardia gastric cancer [24]. Nonetheless the biologic pathways leading from $H$. pylori infection to gastric cancer are not yet well known. Despite the fact that over half the world population is infected, only a small percentage of infected subjects develop the cancer, and as $H$. pylori infection is equally prevalent in men and women, men have approximately twice the risk of gastric cancer. Prevalence of $H$. pylori infection displays important geographic differences worldwide, ranging from $40 \%$ or less in developed countries to $70 \%$ or more in developing countries [25]. According to published studies, Spain is situated in an intermediate position vis-à-vis industrialized and developing countries. Local studies have reported $H$. pylori infection prevalences from as low as $43 \%$ [26] to as high as $69 \%$ [27], but there are still wide areas of our country for which this information is lacking, not making possible to link data of gastric cancer mortality and prevalence of the infection.

Until the discovery of Helicobacter pylori, diet was the most important factor associated with gastric cancer. This is a very complex variable, that includes nutrient intake as well as exposure to contaminants. It is generally accepted that consumption of fruit and vegetables affords protection against the development of this tumor [28-30], whereas salt, and foods with higher levels of $N$-nitroso compounds are deemed to be risk factors [31-33]. In Spain, the foods that most contribute to exposure to nitrites and nitrosamines are meat products, cereals, vegetables and fruit in the case of the former, and processed meat, beer, cheese and broiled fish in the case of the latter [34]. Even so, there is no conclusive evidence as to the relationship between nitrogenated compounds and gastric cancer in humans. Moreover, the effect of such compounds could vary in accordance with intake of other substances, chemical or biologic contaminants and certain dietary components such as vitamins, $H$. pylori infection, and different patterns of genetic susceptibility [35].

The rising south-north and coast-inland gradient observed in the risk pattern, which is particularly marked in Castile \& Leon and continues into Portugal $[23,36]$ has been classically attributed to dietary habits, i.e., areas with regular consumption of cured, smoked and salted food, and low intake of fruit and fresh vegetables [37-40]. However, dietary patterns have changed, and Castile \& Leon has become one of the Spanish regions with higher intake of vegetables and fruits.

An alternative explanation for the described pattern would be the existence of some environmental exposure linked to the geologic characteristics of this region. Areas with highest gastric cancer mortality in the Autonomous Region of Castile \& Leon basically coincide with the Tertiary Duero River Basin, an area in which elevated levels of certain contaminants have been detected, both in soils and in underground waters, principal among which is arsenic [41-44]. Most of the towns affected by this problem, essentially farming communities, rely on underground water for crop irrigation [41,45]. Although the possible existence of contaminants associated with pesticide use is not ruled out, studies undertaken to date mainly link these high levels of arsenic to its presence in the rocky substrate and its subsequent seepage into underground water through natural geochemical mechanisms [41], which in turn suggests that exposure to this toxin among residents in such areas could go back many years.

The presence of arsenic in underground water in concentrations above WHO drinking-water guideline limits is a problem of enormous importance in many areas of the 
a)

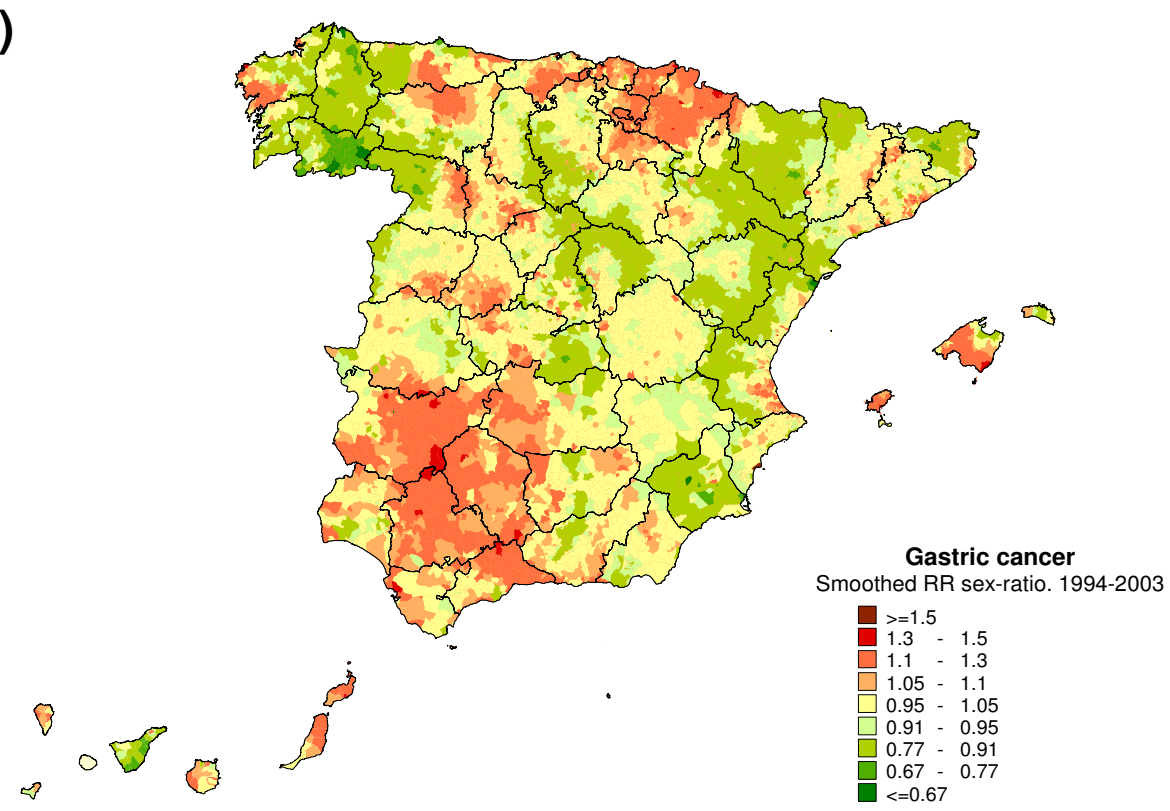

b)

Figure 4

Municipal distribution of: a) gastric cancer sex ratios obtained on the basis of smoothed RRs; b) municipal distribution of lung cancer mortality in men.

world. Curiously, many of the affected countries register the highest rates of gastric cancer worldwide, as is the case with China and Japan.

A possible role of arsenic in gastric carcinogenesis, whether directly or as a co-factor that facilitates the action of another mutagenic agent, seems to be a plausible hypothesis. It is a highly toxic compound that affects the gene repair pathways $[46,47]$ and may, moreover, cause gastric irritation [48]. There is sufficient evidence to show that arsenic in drinking-water causes cancers of the urinary bladder, lung, and skin in humans, and might be related with liver or kidney neoplasms [49]. At present, however, there are few epidemiologic studies that have reported an association between exposure to arsenic and development of gastric cancer [50,51]. Notwithstanding, 
it is interesting to note that gastric cancer incidence and mortality decline in developed countries in the second half of the $20^{\text {th }}$ century, commonly attributed to improvements in food preservation and preparation, also coincides with a decrease in the consumption of water drawn from deep underground sources and the parallel rise in the number of persons supplied with potable water piped from surface sources.

There are other metals too that could also be present in the designated area, due fundamentally to industrial pollution, a major cause of water pollution. According to the data reported to the EPER in 2001, which lists industrial contaminant releases to air and water, Castile \& Leon ranks second in Spain in terms of tons of chrome released directly into water, mainly into the tributaries of the Ebro and Duero Rivers [52]. In relation to chrome emissions, Burgos province -in Castile \& Leon- ranks second at national level, only behind Tarragona, a coastal province which releases part of its waste into the Mediterranean Sea. Hexavalent chrome, a recognized carcinogen, raises the risk of gastric cancer in experimental studies [53]. Its genotoxic and mutagenic effect in vitro is boosted in the presence of certain dietary components [54]. Further data are still needed, however, to clarify the relationship between digestive tumors and exposure to this agent, which, in the general population, is essentially delivered by diet and drinking water.

Other toxins present in the Duero basin are nitrates [55]. Although these occur naturally in some groundwater, in most cases higher levels are thought to result from human activities. In Spain, though drinking water accounts for a small percentage of the total intake of these agents, gastric cancer mortality has been correlated with increasing exposure to nitrates in drinking water, not only in an area with high gastric cancer mortality rates [56] but also in a low risk region $[57,58]$. While similar results have been reported in Hungary [59], there are studies that do not support this hypothesis [60]. It should be noted that nitrate pollution also indicates low water quality and so might be accompanied by other pollutants. Moreover nitrate contamination is a problem common to many Spanish aquifers, and is therefore not specific to high gastric cancer risk areas.

The excess risk displayed by both sexes in the interior of Catalonia has been previously described, and attributed to the more rural, inland population's dietary habits associated with stomach cancer- and to the absence of readily accessible health centers [61]. Nonetheless, the implication of other environmental exposures should not be ruled out. Local aquifers are heavily overexploited, and Catalonia is home to the river basin registering the greatest use of water for human consumption in Spain [62].
With respect to the excess gastric cancer risk observed on the Atlantic Coast of Galicia, it is worth noting that the towns with the highest risks countrywide in both sexes are all situated on the Morrazo Peninsula (Pontevedra province), a small geographic area with over 90,000 inhabitants. The sex ratio in this area is close to unity, something which suggests the possible implication of environmental risk factors. The economy of these towns is based on fishing, preparation of dried and salted fish, and shellfishing, mussel breeding in particular. Contaminants present in the estuaries, such as certain microorganisms, chemical pollutants (heavy metals, persistent organochlorinated pollutants, and polycyclic aromatic hydrocarbons) and marine toxins can indeed rise to high levels in shellfish and crustaceans. Such toxicants would reach the gastric mucosa by ingestion of local fish and seafood. One of these biotoxins is okadaic acid, which is present in mussels and involved in diarrhetic shellfish poisoning. This toxin has been shown to behave as a tumor promoter in mice and been proposed as a cause of digestive cancers in humans [63].

Finally, it should be stressed that the map depicting the male:female ratio of estimated risks at a municipal level suggests that tobacco may play an important role in men in those areas where this ratio is higher, given the similarity between its spatial distribution and the male risk pattern of dying from tobacco-related tumors, such as lung and bladder cancer [64]. In Spain, the prevalence of female smokers until 1960-70 was very low [65]; in fact, time trend in lung-cancer mortality rates in women did not reflect changes in smoking patterns until the 90s, when a increase in mortality among younger generations was detected, showing the early phase of the smokingrelated lung-cancer epidemic among Spanish females [66]. Although the role of tobacco in this tumor's development has been subject of debate for many years, recent studies are furnishing evidence supporting the fact that smoking is an important risk factor for cardia gastric cancer $[67,68]$. Our results are in accord with the consistent relationship found by other authors between tobacco and male stomach cancer, and the lower evidence of this association for females [69].

To sum up, this paper suggests possible environmental hypotheses that might help to explain the persistence of the peculiar spatial gastric cancer mortality pattern over time, similar across the sexes. Some environmental contaminants, such as chrome, arsenic, nitrites or marine toxins delivered via diet and drinking water, could act as genotoxic agents or as irritants of the gastric mucosa. The possible modifying role of those environmental toxicants on the effect of the principal known risk factors, including H. pylori infection, diet, or smoking, could be an interesting topic that would be worth bearing in mind in future studies. 


\section{Abbreviations}

AC: adenocarcinomas; ICD-9: international classification of diseases, 9th revision; RR: relative risk; SMR: standardized mortality ratio; ASR: age-standardized rate.

\section{Competing interests}

The authors declare that they have no competing interests.

\section{Authors' contributions}

GLA, NA, MP, and BPG were all involved in designing the study. GLA, RR and EV performed the statistical analysis. NA wrote the first draft of the manuscript to which all authors subsequently contributed. All authors made contribution to statistical analyses and interpretation of results, and revised the manuscript for important intellectual content. All authors read and approved the final manuscript.

\section{Acknowledgements}

This study was funded by Grant No. EPY-I I 76/02 from the Carlos III Institute of Health (Instituto de Salud Carlos III). The authors would like to thank Michael Benedict for his help with the English and Diana Gómez-Barroso for her help with the mapping.

\section{References}

I. Howson CP, Hiyama T, Wynder EL: The decline in gastric cancer: epidemiology of an unplanned triumph. Epidemiol Rev 1986, 8: I-27.

2. Parkin DM, Bray F, Ferlay J, Pisani P: Global cancer statistics, 2002. CA Cancer J Clin 2005, 55:74-108.

3. Ferlay J, Bray F, Pisani P, Parkin DM: GLOBOCAN 2002: Cancer Incidence, Mortality and Prevalence Worldwide. IARC CancerBase No.5. version 2.0. Lyon, IARCPress; 2004.

4. Lauren PA: The two histological main types of gastric carcinoma: diffuse and so-called intestinal-type carcinoma. An attempt at a histo-clinical classification. Acta Pathol Microbiol Scand 1965, 64:31-49.

5. Lauren PA, Nevalainen TJ: Epidemiology of intestinal and diffuse types of gastric carcinoma. A time-trend study in Finland with comparison between studies from high- and low-risk areas. Cancer 1993, 71:2926-2933.

6. Craanen ME, Dekker W, Blok P, Ferwerda J, Tytgat GN: Time trends in gastric carcinoma: changing patterns of type and location. Am J Gastroenterol 1992, 87:572-579.

7. Karpeh MS, Kelsen DP, Tepper JE: CANCER Principles and Practice of Oncology 6th edition. Edited by: DeVita VTJ, Hellman S, Rosenberg SA. Philadelphia: LIPPINCOTT WILLIAMS AND WILKINS; 2001:1092-I I 26.

8. Crew KD, Neugut Al: Epidemiology of gastric cancer. World J Gastroenterol 2006, I 2:354-362.

9. Nyren O, Adami HO: Stomach Cancer. Edited by: Adami HO, Hunter D, Trichopoulos D. New York: Oxford University Press; 2002.

10. Shibata H, Parsonnet J: Stomach Cancer. In Cancer Epidemiology and Prevention Third edition. Edited by: Schottenfeld D, Fraumeni J. New York: Oxford University Press; 2006:707-720.

II. Resnik DB, Roman G: Health, justice, and the environment. Bioethics 2007, 21:230-24I.

12. Evans GW, Kantrowitz E: Socioeconomic status and health: the potential role of environmental risk exposure. Annu Rev Public Health 2002, 23:303-331.

13. López-Abente G, Pollán M, Escolar A, Errezola M, Abraira V: Atlas de mortalidad por cáncer y otras causas en España, 1978-1992 Madrid: Instituto de Salud Carlos III; 200 I.

14. Elliott P, Wartenberg D: Spatial epidemiology: current approaches and future challenges. Environ Health Perspect 2004, I 2:998-1006.
15. Aragones N, Ramis R, Pollan M, Perez-Gomez B, Gomez-Barroso D, Lope V, Boldo El, Garcia-Perez J, Lopez-Abente G: Oesophageal cancer mortality in Spain: a spatial analysis. BMC Cancer 2007, $7: 3$.

16. Besag J, York J, Mollie A: Bayesian Image-Restoration, with Applications in Spatial Statistics. Annals of the Institute of Statistical Mathematics I991, 43: I-20.

17. Gilks W, Richardson S, Spiegelhalter D: Markov Chain Montecarlo in practise London: Chapman Hall; 1996.

18. Smith BJ: Bayesian Output Analysis Program (BOA), Version I.I.5 for R.

19. Spiegelhalter D, Thomas A, Best N: WinBUGS user manual. Version I.4.I. Cambridge, MRC; 2003.

20. Richardson S, Thomson A, Best N, Elliott P: Interpreting posterior relative risk estimates in disease-mapping studies. Environ Health Perspect 2004, I I 2:1016-1025.

21. Perez-Gomez B, Aragonés N, Pollán M, Suarez B, Lope V, Llácer A, Lopez-Abente G: Accuracy of cancer death certificates in Spain: A summary of available information. Gac Sanit 2006, 20(Suppl):42-5I.

22. López-Abente G, Escolar-Pujolar A, Errezola M: Atlas del cáncer en España Vitoria-Gasteiz: s.e; 1984.

23. IARC: Schistosomes, Liver Flukes and Helicobacter pylori Lyon; 1994.

24. Correa P, Houghton J: Carcinogenesis of Helicobacter pylori. Gastroenterology 2007, I 33:659-672.

25. Brown LM: Helicobacter pylori: epidemiology and routes of transmission. Epidemiol Rev 2000, 22:283-297.

26. Senra-Varela A, Lopez-Saez JB, Gomez-Biondi V: Prevalence of Helicobacter pylori infection in two Spanish regions with different incidence of gastric cancer. Eur J Epidemiol 1998, I4:49|-494.

27. Macenlle GR, Gayoso DP, Sueiro Benavides RA, Fernandez SJ: Prevalence of Helicobacter pylori infection in the general adult population of the province of Ourense. Rev Esp Enferm Dig 2006, 98:24I-248.

28. Gonzalez CA, Pera G, Agudo A, Bueno-de-Mesquita HB, Ceroti M, Boeing H, Schulz M, Del Giudice G, Plebani M, Carneiro F, et al.: Fruit and vegetable intake and the risk of stomach and oesophagus adenocarcinoma in the European Prospective Investigation into Cancer and Nutrition (EPIC-EURGAST). Int J Cancer 2006, I I 8:2559-2566.

29. Lunet N, Valbuena C, Vieira AL, Lopes C, Lopes C, David L, Carneiro $\mathrm{F}$, Barros $\mathrm{H}$ : Fruit and vegetable consumption and gastric cancer by location and histological type: case-control and metaanalysis. Eur J Cancer Prev 2007, 16:3|2-327.

30. Campbell PT, Sloan M, Kreiger N: Dietary patterns and risk of incident gastric adenocarcinoma. Am J Epidemiol 2008, 167:295-304.

31. Correa P, Haenszel W, Cuello C, Tannenbaum S, Archer M: A model for gastric cancer epidemiology. Lancet 1975, 2:58-60.

32. Gonzalez CA, Jakszyn P, Pera G, Agudo A, Bingham S, Palli D, Ferrari $P$, Boeing $H$, Del Giudice G, Plebani M, et al.: Meat intake and risk of stomach and esophageal adenocarcinoma within the European Prospective Investigation Into Cancer and Nutrition (EPIC). J Natl Cancer Inst 2006, 98:345-354.

33. Tsugane S, Sasazuki S: Diet and the risk of gastric cancer: review of epidemiological evidence. Gastric Cancer 2007, 10:75-83.

34. Jakszyn P, Agudo A, Berenguer A, Ibanez R, Amiano P, Pera G, Ardanaz E, Barricarte A, Chirlaque MD, Dorronsoro M, et al.: Intake and food sources of nitrites and $\mathrm{N}$-nitrosodimethylamine in Spain. Public Health Nutr 2006, 9:785-79I.

35. Jakszyn P, Bingham S, Pera G, Agudo A, Luben R, Welch A, Boeing H, Del Giudice G, Palli D, Saieva C, et al.: Endogenous versus exogenous exposure to $\mathbf{N}$-nitroso compounds and gastric cancer risk in the European Prospective Investigation into Cancer and Nutrition (EPIC-EURGAST) study. Carcinogenesis 2006, 27: I497-I50I.

36. Lunet N, Pina F, Barros H: Regional trends in Portuguese gastric cancer mortality (1984-1999). Eur J Cancer Prev 2004, | 3:27|-275.

37. Cayuela A, Vioque J, Rodriguez-Arce A, Rojas M, Jimenez-Mengibar C: [Geographic differences in mortality from digestive tumors in Spain, 1980-1984]. Gac Sanit 1991, 5:72-8I.

38. Corella D, Cortina P, Guillen M, Gonzalez Jl: Dietary habits and geographic variation in stomach cancer mortality in Spain. Eur J Cancer Prev 1996, 5:249-257. 
39. da Motta LC: Epidemiology of gastric cancer in Portugal. Eur J Cancer Prev 1994, 3(Suppl 2): I I-I2.

40. Vioque J, Egea CM, Porta M: Stomach cancer mortality in Spain: an ecological analysis of diet, altitude, latitude, and income. J Epidemiol Community Health 1995, 49:44I-442.

4I. Sahún B, Gómez JJ, Lillo J, del Olmo P: Arsénico en aguas subterráneas e interacción agua-roca: un ejemplo en la cuenca terciaria del Duero (Castilla y León, España). Rev Soc Geol España 2008, 17:137-155.

42. García-Sánchez A, Álvarez-Ayuso E: Arsenic in soils and waters and its relation to geology and mining activities (Salamanca Province, Spain). J Geochem Explor 2003, 80:69-79.

43. García-Sánchez A, Moyano A, Mayorga P: High arsenic contents in groundwater of central Spain. Environ Geol 2005, 47:847-854.

44. García-Villanueva RJ, Rodríguez P, Toruño I, González AM, Gómez JA, Cordón $\mathrm{C}$ : Arsenic in ground drinking water. Ther regional monitoring plan of Castilla y León (Spain). Eur J Water Quality 2005, 36:107-117.

45. Calvo-Revuelta C, Álvarez-Benedí J, Andrade-Benitez M, MarineroDiez P, Bolado-Rodríguez S: Contaminación por arsénico en aguas subterráneas en la provincia de Valladolid: variaciones estacionales. Edited by: Álvarez-Benedí J, Marinero P. Valladolid: Instituto Tecnológico Agrario de Castilla y León (I.T.A.); 2003:91-98.

46. Salnikow K, Zhitkovich A: Genetic and epigenetic mechanisms in metal carcinogenesis and cocarcinogenesis: nickel, arsenic, and chromium. Chem Res Toxicol 2008, 21 :28-44.

47. Rossman TG, Uddin AN, Burns FJ, Bosland MC: Arsenite cocarcinogenesis: an animal model derived from genetic toxicology studies. Environ Health Perspect 2002, I I O(Suppl 5):749-752.

48. Kapaj S, Peterson H, Liber K, Bhattacharya P: Human health effects from chronic arsenic poisoning--a review. J Environ $\mathrm{Sci}$ Health A Tox Hazard Subst Environ Eng 2006, 4 I:2399-2428.

49. IARC: Some Drinking-water Disinfectants and contaminants, including Arsenic Lyon; 2004.

50. Wall S: Survival and mortality pattern among Swedish smelter workers. Int J Epidemiol 1980, 9:73-87.

5I. Bulbulyan MA, Jourenkova NJ, Boffetta P, Astashevsky SV, Mukeria $A F$, Zaridze DG: Mortality in a cohort of Russian fertilizer workers. Scand J Work Environ Health 1996, 22:27-33.

52. Ministry of the Environment and Rural and Marine Environs: Spanish Register of Emission and Pollutant Sources. [http:// www.en.prtr-es.es/].

53. Beaumont JJ, Sedman RM, Reynolds SD, Sherman CD, Li LH, Howd RA, Sandy MS, Zeise L, Alexeeff GV: Cancer mortality in a Chinese population exposed to hexavalent chromium in drinking water. Epidemiology 2008, 19:12-23.

54. Reynolds $M$, Zhitkovich A: Cellular vitamin $C$ increases chromate toxicity via a death program requiring mismatch repair but not p53. Carcinogenesis 2007, 28:1613-1620.

55. Ministry of the Environment and Rural and Marine Environs: Confederación Hidrográfica del Duero. [http://www.chduero.es/].

56. Sanz Anquela JM, Munoz Gonzalez ML, Ruiz Liso JM, Rodriguez ML, Alfaro T]: [Correlation of the risk of gastric cancer in the province of Soria and the nitrate content of drinking water]. Rev Esp Enferm Apar Dig 1989, 75:561-565.

57. Gonzalez CA, Riboli E, Badosa J, Batiste E, Cardona T, Pita S, Sanz JM Torrent M, Agudo A: Nutritional factors and gastric cancer in Spain. Am J Epidemiol 1994, 139:466-473.

58. Morales-Suarez-Varela MM, Llopis-Gonzalez A, Tejerizo-Perez ML: Impact of nitrates in drinking water on cancer mortality in Valencia, Spain. Eur J Epidemiol 1995, I I:I5-2I.

59. Sandor J, Kiss I, Farkas O, Ember I: Association between gastric cancer mortality and nitrate content of drinking water: ecological study on small area inequalities. Eur J Epidemiol 200I, I 7:443-447.

60. Barrett JH, Parslow RC, McKinney PA, Law GR, Forman D: Nitrate in drinking water and the incidence of gastric, esophageal, and brain cancer in Yorkshire, England. Cancer Causes Control 1998, 9:153-159.

6I. Puig X, Gispert R, Ginebra J, Bisbe J: Mortalidad por cáncer de estómago en Cataluña: distribución geográfica y evolución temporal entre 1986 y 2000. Med Clin (Barc) 2006, I 26:48I-484.

62. Greenpeace: Agua. La calidad de las aguas en España. Un estudio por cuencas 2005.

63. Cordier S, Monfort C, Miossec L, Richardson S, Belin C: Ecological analysis of digestive cancer mortality related to contamina- tion by diarrhetic shellfish poisoning toxins along the coasts of France. Environ Res 2000, 84: 145-150.

64. Lopez-Abente G, Aragones N, Ramis R, Hernandez-Barrera V, PerezGomez B, Escolar-Pujolar A, Pollan M: Municipal distribution of bladder cancer mortality in Spain: possible role of mining and industry. BMC Public Health 2006, 6: I7.

65. Fernandez E, Schiaffino A, Borras JM, Shafey O, Villalbi JR, La Vecchia C: Prevalence of cigarette smoking by birth cohort among males and females in Spain, 1910-1990. Eur J Cancer Prev 2003, I 2:57-62.

66. Franco J, Perez-Hoyos S, Plaza P: Changes in lung-cancer mortality trends in Spain. Int J Cancer 2002, 97:102-105.

67. Gonzalez CA, Pera G, Agudo A, Palli D, Krogh V, Vineis P, Tumino R, Panico S, Berglund G, Siman H, et al.: Smoking and the risk of gastric cancer in the European Prospective Investigation Into Cancer and Nutrition (EPIC). Int J Cancer 2003, 107:629-634.

68. Ladeiras-Lopes R, Pereira AK, Nogueira A, Pinheiro-Torres T, Pinto I, Santos-Pereira R, Lunet N: Smoking and gastric cancer: systematic review and meta-analysis of cohort studies. Cancer Causes Control 2008, 19:689-70I.

69. Chao A, Thun MJ, Henley SJ, Jacobs EJ, McCullough ML, Calle EE: Cigarette smoking, use of other tobacco products and stomach cancer mortality in US adults: The Cancer Prevention Study II. Int J Cancer 2002, I 0 I:380-389.

\section{Pre-publication history}

The pre-publication history for this paper can be accessed here:

\section{http://www.biomedcentral.com/1471-2407/9/316/pre} pub
Publish with Bio Med Central and every scientist can read your work free of charge

"BioMed Central will be the most significant development for disseminating the results of biomedical research in our lifetime. "

Sir Paul Nurse, Cancer Research UK

Your research papers will be:

- available free of charge to the entire biomedical community

- peer reviewed and published immediately upon acceptance

- cited in PubMed and archived on PubMed Central

- yours - you keep the copyright
BioMedcentral 